\title{
Thermal pants may reduce the risk of recurrent hamstring injuries in rugby players
}

\section{MRC/UCT}

Bioenergetics of

Exercise Research

Unit,

Department of

Physiology,

University of Cape

Town Medical School,

South Africa

P A H Upton

T D Noakes

Department of Statistical Sciences

J M Juritz

Correspondence to: Professor T D Noakes, MRC/UCT Bioenergetics of Exercise Research Unit, Department of Physiology, Sports Science Institute of South Africa, Boundary Road, Newlands, 7700 Republic of South Africa

Accepted for publication 20 July 1995

P A H Upton, T D Noakes, J M Juritz

\begin{abstract}
Objective-To determine whether the use of thermal pants might reduce the risk of hamstring injury in rugby players.

Methods-44 male rugby players from the Cape Province, South Africa, who had previously suffered a hamstring injury were given the choice of wearing thermal warming pants or not, and were then monitored for the development of hamstring injuries during the 1992 season.

Results-In the group who wore warmers some of the time, the injury rate was significantly lower when using the warmers ( 3 injuries/1000 playing hours) than when not (57/1000 playing hours). There was no difference in injury rates between groups who either wore warmers all the time or none of the time, probably because the number who wore the warmers all the time was small $(n=5)$. Eighteen percent of the injuries recurred at exactly the same site in the muscle and within $12 \mathrm{~d}$ of returning to rugby after the initial injury. The incidence of injury was high in the first three weeks of the season and again in the same period after the mid-season break. More than $80 \%$ of all match and practice time lost by these players during the study was a direct result of their hamstring injuries.

Conclusions-Thermal pants may have a role in preventing recurrent hamstring injuries but other factors such as inadequate preseason training and incomplete rehabilitation after injury are likely to be more significant risk factors for injury.

(Br $\mathcal{F}$ Sports Med 1996;30:57-60)
\end{abstract}

Key terms: thermal pants; hamstring muscle injuries; injury rate

The hamstring muscles, which are biarticular muscles with a predominance of fast twitch fibres ${ }^{1}$ are the most commonly injured muscles in athletes. ${ }^{2} 3$ These injuries can be devastating because they frequently heal slowly and often become recurrent as a result of inadequate treatment and rehabilitation. ${ }^{13}{ }^{4}$ Many of these injuries are believed to be avoidable. ${ }^{24}$ Aetiological risk factors that have been identified for these injuries include inadequate warm up, incorrect stretching, inflexibility, muscle strength imbalance, fatigue, previous injury, intramuscular corticosteroid injections, and return to activity before complete rehabilitation following injury. ${ }^{1-4}$ In addition, recent research on rabbit muscle has shown that muscle warming increases the amount of force and length of stretch necessary to tear the muscle. ${ }^{5}$ This suggests that warming of muscle might reduce the probability that it will be injured during exercise.

Interestingly, recent rugby seasons have been characterised by an increasing use by rugby players of thermal or neoprene pants. The practice seems to have evolved spontaneously and without any scientific assessment of its value. Accordingly we wished to determine whether the use of these pants might reduce the risk of hamstring injury.

\section{Methods}

Sixty rugby players from 10 Western Cape clubs who reported that they had missed seven days of rugby or more due to a hamstring injury during either of the previous two playing seasons, were identified as subjects. Subjects gave their informed consent to be monitored for the duration of the 1992 rugby playing season.

Each player completed a hamstring injury questionnaire which included the following details:

(1) personal details; name, height, weight, date of birth; club, team, playing position.

(2) injury history; details of initial hamstring injury including when it occurred, how it occurred, to which leg, what strapping or protection was used at the time of injury, days off rugby as a result of hamstring injury, which part of the muscle was injured, style of boots worn, similar details regarding any recurrent injuries, what protective aids are presently being used and how often during training and matches they are used.

(3) details of warm up and stretching routines and how frequently the routine is followed.

Players were given the choice of wearing or not wearing the thermal warmers during the season. The pants were made from closed cell neoprene material $(1.5 \mathrm{~mm}$ thick) with nylon laminated on both sides and had an inside leg length of $25 \mathrm{~cm}$. They were manufactured and supplied by Medac (Pty) Ltd, Cape Town, South Africa.

During the course of the season the following information was obtained on a weekly basis by postal questionnaires which were returned at the end of every three week cycle: (1) Did the player participate fully in all team training sessions? (2) Reason for not participating; (3) Were thermal pants worn at training? (4) Number of matches played; 
(5) Reasons for not playing matches; (6) Were pants worn during matches? (7) Any comments the player felt might be relevant to the study.

At approximately six weekly intervals personal contact was made with each player to confirm the return of the relevant forms and to clarify ambiguous data.

If at any stage during the season a player sustained a hamstring injury, defined as a muscle strain that caused the player to be unable to run unhindered and at full speed at any time during a match or training, he was required to complete an injury questionnaire. This questionnaire obtained information on the following:

(1) Injury details: date, site of injury in muscle, which leg, whether injury occurred during a match, training or another situation, when during practice, in which quarter during match, how injury occurred, severity of injury which was measured in days off rugby (mild $<14 \mathrm{~d}$, moderate 14-28 d, severe strain $>28 \mathrm{~d}$ ), protective device used at the time of injury, whether player was in possession of the ball or not, condition of the playing field, weather conditions.

(2) Warming up and stretching routine followed within $2 \mathrm{~h}$ before the injury occurred.

(3) What medical or other treatment was given.

Three subject groups were studied: group I, who wore thermal pants on the previously injured leg during training and matches for the entire duration of the season $(n=5)$; group II, who never wore these pants $(n=17)$; and group III, who wore the thermal pants some of the time and other times not $(n=22)$. Time spent wearing, and time spent not wearing the pants during training or competition was determined for players in group III.

\section{ANALYSIS OF DATA}

Comparison of survival time (playing minutes) until injury was calculated for groups I and II. If a player sustained a hamstring injury severe enough to keep him out of rugby for $14 \mathrm{~d}$ or more, and then suffered a second injury at exactly the same site in the same hamstring muscle within $12 \mathrm{~d}$ of returning to rugby, the second injury was considered an extension of the original injury and was thus excluded from the initial calculations.

Data were analysed using a Quattro Pro spreadsheet (Borland International). The survival time to injury was calculated as the number of minutes played before an injury occurred in a player. The mean survival time to injury for groups I and II were compared using BMDP1L. ${ }^{8}$ The Kaplan-Meier survivor functions ${ }^{9}$ were calculated using BMDP1L. The generalised Wilcoxon test ${ }^{10}$ was used to compare the difference between the survival curves of the two groups. Statistical significance was established at $\mathbf{P}<0.05$.

Analysis of the injury rate per 1000 hours played was calculated for groups I and II as well as for the time spent wearing or not wearing thermal pants for the subjects in group III. To test the hypothesis that the two rates are the same, a different test was used for each of these groups; the Poisson Rates formula on the STATSGRAPHICS package (Statistical Graphics Co) was used for groups I and II, and a non-parametric test, the Wilcoxon Signed rank test, was used to compare the injury rate for subjects in group III when wearing and not wearing pants.

\section{Results}

SUBJECT CHARACTERISTICS

Forty four of the 60 subjects completed the study $(73 \%)$. Of the 16 players who did not complete the study, six stopped playing rugby early in the season for various reasons and 10 repeatedly did not return questionnaires. The mean (SD) age of the players was 23(3) years. There were four tight forwards, eight loose forwards, and 32 backline players. Thirty two percent of the players had previously worn the thermal pants.

INJURIES BEFORE THE 1992 SEASON

The initial hamstring injury suffered before the 1992 rugby season kept the players off rugby for an average of 23(30) d. All these injuries resulted from playing or training for rugby. Eighteen of the 44 players who completed the study suffered recurrent injuries: two players were injured a further five times, six players twice, and 10 players once.

\section{WEARING OF THERMAL PANTS OVER THE}

SEASON

Table 1 shows the total playing time (h) completed by 44 subjects, the hours played while wearing thermal pants, the total hours missed as the result of any injury, and the hours missed specifically due to hamstring injury. Thermal pants were worn for nearly half of the time spent in practice $(48 \%)$ or in match play $(49 \%)$. Injury caused players to miss $39 \%$ of the scheduled match hours; $85 \%$ of this lost playing time was due to hamstring injuries. Similarly players missed $42 \%$ of the scheduled practice hours, $83 \%$ as a result of hamstring injuries.

\section{INJURY RATES}

Table 2 shows the overall time played, number of injuries, and injury rates for players in groups I, II, and III. Five players wore thermal pants for the entire season (group I) and 17 never wore pants (group II). The respective injury rates were 24 and 32 injuries per thousand playing hours which were not significantly different $(P=0.63)$.

In group III, thermal pants were worn for $67 \%$ of the playing hours, while no protection was worn the remainder. The injury rate of three injuries per thousand hours for the group wearing thermal pants was significantly less $(P<0.05)$ than the 57 injuries per thousand hours for the non-users. If eight early recurrent injuries (within $12 \mathrm{~d}$ of return) are included in the wearer group, the rate rises to 16 injuries per thousand hours, which is still significantly 
Table 1 Total playing time (hours) completed by 44 subjects, hours played while wearing warmers, total hours missed, and hours missed due to hamstring injury

\begin{tabular}{lclcl}
\hline & $\begin{array}{l}\text { Total hours } \\
\text { completed }\end{array}$ & $\begin{array}{l}\text { Completed wearing } \\
\text { thermal warmers }\end{array}$ & $\begin{array}{l}\text { Hours } \\
\text { missed }\end{array}$ & $\begin{array}{l}\text { Missed due to } \\
\text { hamstring injury }\end{array}$ \\
\hline Matches & 504 & 246 & 328 & 275 \\
Practices & 1391 & 670 & 1008 & 832 \\
\hline
\end{tabular}

less $(P<0.05)$ than the incidence in the group who wore no protection.

SURVIVAL TIMES TO INJURY - GROUPS I AND II The survival curves for groups I and II are shown in the figure. The mean (SE) survival time without injury for players in group I was $24 \cdot 8$ (3) $\mathrm{h}$, and for players in group II was $35 \cdot 2$ $(7 \cdot 8) \mathrm{h}$; these values were not significantly different $(P=0 \cdot 23)$. But at the end of the study the five players in group I were still not injured after $58.5 \mathrm{~h}$, whereas all 17 players in group II had been injured after $62 \cdot 0 \mathrm{~h}$.

\section{DETAILS ON INJURIES SUSTAINED DURING THE} SEASON

Of the 60 hamstring injuries suffered by these players, $40 \%$ occurred during two three-week periods, at the start of the season and after the mid-season break; $42 \%$ recurred at exactly the same site as the previous injury; $90 \%$ were moderate or major tears; $55 \%$ occurred during practices and $45 \%$ during matches. Seventy eight percent of hamstring injuries suffered during match play occurred in the second half of the game.

\section{Discussion}

The main finding of this study was that the hamstring injury rate among players in group

Table 2 Overall time playing rugby, number of injuries and early recurrent injuries, and injury rates per thousand hours of play for players in groups I, II, and III

\begin{tabular}{lcccc}
\hline & Group I & Group II & \multicolumn{2}{l}{ Group III } \\
\cline { 5 - 5 } & & & Wearing & Not wearing \\
\hline Total players & 5 & 17 & 22 & 22 \\
Total playing time (h) & 246 & 680 & 654 & 315 \\
Total injuries sustained & 8 & 24 & 10 & 18 \\
Early recurrent injuries & 2 & 2 & 8 & 0 \\
Injury rate/1000 h play & $24^{\star}$ & 32 & $3 \dagger$ & 57 \\
\hline
\end{tabular}

Not significant $(P=0.63)$

†Significant $(\mathrm{P}<0.05)$.
III was significantly lower when they wore the thermal pants than when they did not. This is especially interesting because of the possibility that players who believe that the use of these pants reduces the risk of injury would be more likely to wear them when they believed injury to be more likely.

Although no significant difference between injury rates was found between players who wore thermal pants at all times and those who never wore them, the former group consisted of only five players. The small sample size may have prevented a statistically significant finding. Furthermore the survival curves suggest that the group who wore thermal pants all the time had a longer injury-free period. Hence this study provides preliminary evidence which suggests that thermal pants might have a role in preventing recurrent hamstring injuries.

Other relevant findings were that $18 \%$ of the hamstring injuries in this study recurred at exactly the same site in the muscle and within 12 days of the player returning to rugby after the initial injury. This confirms the finding that many acute hamstring injuries become recurrent as a result of inadequate treatment or rehabilitation, with the athlete returning to active participation before full recovery has occurred. ${ }^{12}$

The high incidence of hamstring injury in the first three weeks of the season and in the first three weeks after the mid-season break supports the findings of Roux et $a l^{11}$ who proposed that the reason was lack of "match fitness". Stanton and Purdam ${ }^{3}$ have suggested that many injuries occur because of "poor conditioning" at the beginning of a competitive season.

The importance of preventing hamstring injuries is shown by the findings that over $80 \%$ of all match and practice time lost by the injured players in this study was a direct result of their hamstring injuries. Muckle ${ }^{4}$ also found that the amount of playing time lost as a result of hamstring injuries was disproportionately high when compared to the overall incidence of this injury.

In summary, we have shown that the wearing of thermal pants can reduce the risk of hamstring injury during rugby. However, other risk factors for injury are probably more important. These include levels of pre-season physical fitness, correct warm up and stretching procedures before activity, and adequate rehabilitation before returning to activity following injury.

This research was funded by Medac (Pty) Ltd. The support of Mr. Kevin Katz, Director of Medac, is gratefully acknowledged. Additional support was provided by the Medical Research Council and the Staff Research Fund of the University of Cape Town.

1 Agre JC. Hamstring injuries; proposed aetiological factors, prevention and treatment. Sports Med 1985;2:21-33.

2 Safran MR, Seaber AV, Garrett WE Warm-up and muscle injury prevention: an update. Sports Med 1989; injury prev

3 Stanton P, Purdam C. Hamstring injuries in sprinting - the role of eccentric exercise. FOSPT 1989;10:343-9.

4 Muckle DS. Associated factors in recurrent groin and hamstring injuries. Br $₹$ Sports Med 1982;16:37-9.

Strickler T, Malone T, Garrett WE. The effects of passive warming on muscle injury. Am $\mathcal{F}$ Sports Med 1990; 
6 Safran MR, Garrett WE, Seaber AV, Glisson RR, Ribbeck $B M$. The role of warm-up in muscle injury prevention. Am $\mathcal{F}$ Sports Med 1988;16:123-9.

7 Shelloch FG, Prentice WE. Warm-up and stretching for improved physical performance and prevention of sportsrelated injuries. Sports Med 1985;2:267-78.

8 Dixon WJ, Brown MD, Engelman L, Frane JW, Hill $M$

Jenrich RI, et al. BMDP statistical software. California:

Jenrich RI, et al. BMDP statistical
University of California Press, 1985.
9 Kaplan EL, Meier. Non parametric estimation from incomplete observations. 7 Am Stat Assoc 1958;53: 457-81.

10 Gross AJ, Clark V. Survival distribution; reliability applications in the biomedical sciences. New York: John Wiley, 1975.

11 Roux CE, Goedeke R, Visser GR, van Zyl WA, Noakes TD. The epidemiology of schoolboy rugby injuries. $S$ Afr Med $\mathcal{f} 1987 ; 71: 307-13$.

\begin{tabular}{|c|c|c|}
\hline \multicolumn{3}{|c|}{ Forthcoming Regional Events } \\
\hline $\begin{array}{l}\text { London and } \\
\text { South East } \\
\text { Region }\end{array}$ & $\begin{array}{l}1 \text { February } 1996 \\
2 \text { April } 1996 \\
7 \text { May } 1996\end{array}$ & $\begin{array}{l}\text { The Sporting Ankle, Guy's, London } \\
\text { Please contact Dr Adrian Rawlinson on } 01818915607 \\
\text { 'Shinsplints' the aerobics nightmare, diagnosis and } \\
\text { treatment, Milton Keynes Dr Simon Petrides } \\
\text { Fast bowling injury, Milton Keynes Dr Philip Bell } \\
\text { For both the above please contact foanne Bratby on } 01908 \\
604666\end{array}$ \\
\hline Joint Meeting & 4 May 1996 & $\begin{array}{l}\text { Rowing Medicine Symposium, Dept of Sports } \\
\text { Medicine, The London Hospital Dr Peter Thomas, } \\
\text { Dr Brian Miller et al. } \\
\text { Joint Meeting - Eastern and London and South East } \\
\text { Regions. } \\
\text { Please contact Dr Adrian Rawlinson on } 01818915607\end{array}$ \\
\hline Northern Region & $\begin{array}{l}\text { February } 1996 \\
\text { April } 1996\end{array}$ & $\begin{array}{l}\text { Women in Sport Jenny Roberts, Cathy Speed and } \\
\text { Jean Wills } \\
\text { Cricket Injuries, Durham } \\
\text { For both the above please contact Andrew Walton on } 0191491 \\
1808\end{array}$ \\
\hline Northern Ireland & $\begin{array}{l}24 \text { January } 1996 \\
6 \text { March } 1996 \\
31 \text { October- } \\
3 \text { November } 1996\end{array}$ & $\begin{array}{l}\text { Problems of the foot, ankle and gait, Belfast } \\
\text { The Sporting Hip and Groin, Belfast City Hospital } \\
\text { BASM Congress (Northern Ireland) } \\
\text { Please contact Dr Bruce Thompson on } 01232653682\end{array}$ \\
\hline Scotland & $\begin{array}{l}17 \text { January } 1996 \\
20 \text { February } 1996 \\
13 \text { March } 1996 \\
\text { 29-31 March } 1996\end{array}$ & $\begin{array}{l}\text { Anatomy of Sacro-iliac Joint and Lower Limb } \\
\text { Practical Gait Analysis } \\
\text { The New Lactate Story } \\
\text { Please contact Dr Faith Gardner on } 01563537306 \\
\text { Advanced Sports Nutrition Course, Pollock Halls, } \\
\text { Edinburgh } \\
\text { Please contact the Education Office by telephone } 0171253 \\
\text { 3244, fax } 01712510774 \text { or E-mail b_hill@uk.ac.lon.barts.vI } \\
\text { Advanced Module covering Spinal Surgery, Disabled } \\
\text { Sports, Rugby and Football Injuries and Casualty Scenarios, } \\
\text { Carlton Highland } \\
\text { Please contact Dr Faith Gardner on } 01563537306\end{array}$ \\
\hline $\begin{array}{l}\text { South West } \\
\text { Region }\end{array}$ & $\begin{array}{l}13 \text { March } 1996 \\
8 \text { June } 1996\end{array}$ & $\begin{array}{l}\text { Skiing Injuries, Avon Ski Centre (Free skiing after!) } \\
\text { Upper Limb Injuries, Swindon } \\
\text { For both the above, please contact Dr Andy Langton on } 01275 \\
854300\end{array}$ \\
\hline Wales & 25 January 1996 & $\begin{array}{l}\text { Women in Sport, Swansea Dr John Fox } \\
\text { Please contact Dr Mark Ridgewell on } 01792361362\end{array}$ \\
\hline Yorkshire & 8 February 1996 & $\begin{array}{l}\text { Compartment Syndrome and Shin Splints } \\
\text { Mr Nat Padia and Mr Mike Allen } \\
\text { Please contact Dr Stephen Feldman on } 01132381180\end{array}$ \\
\hline
\end{tabular}

